\title{
Egg shell treatment methods effect on commercial eggs quality
}

\author{
Métodos de tratamento de casca sobre a qualidade de ovos comerciais
}

\author{
Dayane Santos de Almeida ${ }^{I}$ Aline Félix Schneider ${ }^{I^{*}}$ Flavio Manabu Yuri \\ Bárbara Dalazen MachadoII Clóvis Eliseu Gewehr ${ }^{\text {III }}$
}

\section{ABSTRACT}

The objective was to evaluate commercial eggs quality after being subjected to a cleaning process and immersion in whey protein concentrate (WPC) as a function of storage time. The experimental design was completely randomized in a factorial $4 \times 7$, being four methods of treating shell (not cleaned and not coated with WPC, not cleaned and coated with WPC, cleaned and not coated with WPC, cleaned and coated with WPC and seven periods of storage $(1,7,14,21,28,35$ and 42 days) for a total of 28 treatments, with five replicates of four eggs each. Quality parameters evaluated were weight loss of eggs (\%), specific gravity $\left(\mathrm{g} / \mathrm{cm}^{3}\right)$, haugh units $(\mathrm{HU})$, yolk index (YI) and potential hydrogen $(\mathrm{pH})$ albumen. The storage period increase, regardless of the shell treatment method, causing weight loss in eggs, reductions in specific gravity in the Haugh units, yolk index and increase in the albumen $\mathrm{pH}$. The cleaning method makes egg's internal quality worse during storage. Coverage of whey protein concentrate is a viable alternative for commercial eggs conservation stored at room temperature in order to minimize quality loss during storage, including eggs that need to go through the cleaning process.

Key words: food, laying hens, storage, whey protein concentrate RESUMO

O objetivo deste trabalho foi avaliar a qualidade de ovos comerciais de poedeiras submetidos aos processos de higienização e cobertura com solução de concentrado proteico de soro de leite (CPSL) em diferentes periodos (dias) de armazenamento, em temperatura ambiente. $O$ delineamento foi inteiramente casualizado, em arranjo fatorial $4 x 7$, sendo quatro métodos de tratamento de casca (não-higienizados e não cobertos com CPSL; não-higienizados e cobertos com CPSL; higienizados e não cobertos com CPSL; higienizados e cobertos com CPSL) e sete períodos de armazenamento $(1,7,14,21,28$, 35 e 42 dias), totalizando 28 tratamentos, com cinco repetições de quatro ovos. Avaliou-se a perda de peso dos ovos (\%), gravidade especifica $\left(\mathrm{g} / \mathrm{cm}^{3}\right)$, unidade Haugh (UH), indice de gema (IG) e potencial hidrogeniônico $(\mathrm{pH})$ do albúmen. O tempo de estocagem, independente do método de tratamento de casca, ocasionou perda de peso nos ovos, reduções na gravidade especifica, na unidade Haugh e no índice de gema e aumento no $\mathrm{pH}$ do albúmen $(P<0,05)$. O método de higienização reduz a qualidade interna do ovo com o tempo de armazenamento. A cobertura de concentrado proteico de soro de leite aplicado em ovos higienizados ou não higienizados melhora a qualidade interna dos ovos com o tempo de armazenamento, constituindo-se em uma alternativa viável para conservar ovos comerciais, higienizados ou não, armazenados em temperatura ambiente, minimizando a perda de qualidade interna dos ovos com o tempo de armazenamento.

Palavras-chave: alimentos, armazenamento, concentrado proteico de soro de leite, galinhas poedeiras.

\section{INTRODUCTION}

The egg's internal quality decreases with prolonged storage, and change index in albumen and yolk regarding temperature and carbon dioxide movement through the shell (ROMANOFF \& ROMANOFF, 1963; ORDÓNEZ, 2005). The eggs stored at room temperature or higher than recommended preserve the internal quality for a longer time since the shell becomes impermeable to carbon dioxide (FIUZA et al., 2006).

Egg washing procedures improve their appearance for marketing (CASTELLÓ LLOBET et

\footnotetext{
IPrograma de Pós-graduação em Ciência Animal, Centro de Ciências Agroveterinárias (CAV), Universidade do Estado de Santa Catarina (UDESC), 88520-000, Lages, SC, Brasil. E-mail: aline schneider@hotmail.com. "Corresponding author.

"Programa de Iniciação Científica, CAV, UDESC, Lages, SC, Brasil

IIIDepartamento de Produção Animal e Alimentos, CAV, UDESC, Lages, SC, Brasil. 
al., 1989) and reduce contamination risks. Brazilian regulations (BRASIL, 1990) recommend eggs washing before breaking. However, it is known that the washing step is also carried out in eggs marketed in natura and not only in the eggs to be industrialized. Hygiene is still an issue that generates controversy in the case of egg quality since physical damage may occur to the product when removing the protective cuticle that covers the eggshell. Consequently, eggs are more exposed to the exchange of gases, moisture and microorganisms' entry, speeding up the process of deterioration (STRINGHINI et al., 2009). In this context, whey proteins are gaining prominence in the coverage of food products because they produce flexible, transparent and odorless roofing when processed correctly (GENNADIOS et al., 1994). Also, they may promote shell's pores closing, reducing moisture loss, gas exposure and extending the storage time (KESTER \& FENNEMA, 1986).

The study's aim to evaluate physical and chemical qualities of commercial eggs submitted to the processes of cleaning and immersion in whey protein concentrate, depending on the storage time.

\section{MATERIAL AND METHODS}

It was possible to use 560 commercial brown eggs from Hissex Brown laying hens, with 74 weeks old and from commercial poultry farms for the experiment. Half of the collected eggs were sanitized by mechanical egg washing (Yamasa, LCHS-108.000) with water at room temperature and a solution of sodium hypochlorite (2ppm), and the other half had no washing. There was a subdivision of the two groups. Then, one group was coated with a layer of Whey Protein Concentrate (WPC), and the other group was not coated with the layer. The eggs were immersed in WPC solution for 1 minute and dried at room temperature. The coating solution was prepared according to the methodology adapted from ANTUNES (2003): $539 \mathrm{~g}$ of WPC (80\% protein), $17,5 \mathrm{~g}$ of glycerol dissolved in $500 \mathrm{~g}$ of water $(\mathrm{p} / \mathrm{p})$. Solution was homogenized slowly with a magnetic stirrer until its complete dissolution and immersed in water at $90^{\circ} \mathrm{C}$, for $30 \mathrm{~min}$. After that, it was cooled to $25^{\circ} \mathrm{C}$ and adjusted to $7.0 \mathrm{pH}$ with $1.0 \mathrm{~N} \mathrm{NaOH}$. All eggs were placed in sanitized plastic flats and stored at room temperature. During the assessments, the average temperature of the storage room was $20.2^{\circ} \mathrm{C}$, with an average humidity of $68 \%$ and both measured daily with digital thermo-hygrometer.

The experimental design was completely randomized in a factorial $4 \times 7$ and four methods of shell treating were used: not cleaned and without WPC coverage (NCNC); not cleaned with WPC coverage (NCC); cleaned and without WPC coverage (CNC), cleaned with WPC coverage (CC) and seven storage periods $(1,7,14,21,28,35$ and 42 days) for a total of 28 treatments, with five replicates of four eggs each. Eggs were weighed before storage and at the end of each period to determine weight loss. It was possible to calculate the loss in grams as the difference between initial weight and weight obtained after the storage period and converted into a percentage (BARBOSA et al., 2008). Specific gravity was obtained by using thirteen salt solutions $\left(\mathrm{g} \mathrm{cm}^{-3}\right)$ with densities between 1.040 and 1.110 at 0.005 intervals. Eggs were submerged in the solutions from an area of low concentration to one of high concentration and removed when floating; and the specific gravity was indicated by the solution where the egg emerged from (CASTELLÓ LLOBET et al., 1989). Thus, the eggs were broken on a flat glass surface, and the thick albumen height $(\mathrm{mm})$ was measured with a digital caliper. The equation $\mathrm{HU}=100 \times \log \left(\mathrm{H}-1,7 \mathrm{P}^{0,37}+7,57\right)$, described by Nesheim, Austic and CARD (1979), was used to determine Haugh units (HU), where: HU = Haugh units; $\mathrm{H}=$ albumen height $(\mathrm{mm})$ and $\mathrm{P}=$ egg weight $(\mathrm{g})$. The yolk height was measured with a digital caliper, and its diameter was measured with an analog caliper, after separating yolk and albumen. The relation between these two parameters provided the yolk index: $\mathrm{YI}=\mathrm{YH} / \mathrm{DY}$, where: $\mathrm{YI}=$ yolk index; $\mathrm{YH}=$ yolk height $(\mathrm{mm})$ and $\mathrm{DY}=$ diameter of yolk $(\mathrm{mm})$. The $\mathrm{pH}$ was measured with a digital $\mathrm{pH}$ meter by direct insertion of the electrode into the albumen, and the device was calibrated at every evaluation date.

The average results from cleaning and coverage methods, in each period, were subjected to analysis of variance and the significant differences compared by using a Duncan test, with 5\% significance level (SAS, 1999). Subsequently, data was subjected to regression analysis due to storage time.

\section{RESULTS AND DISCUSSION}

Treatment methods effects of egg shell and storage time factors were significant $(\mathrm{P}<0.05)$ for all variables, as well as the interaction between the two factors $(\mathrm{P}<0.05)$. Weight loss (Table 1) in cleaned eggs and eggs not coated with WPC was higher $(\mathrm{P}<0.05)$ compared to not cleaned eggs, on day 7; however, it was similar $(\mathrm{P}>0.05)$ to the cleaned coated eggs. From day 21 of storage, weight loss in eggs that were neither sanitized nor coated with WPC was higher $(\mathrm{P}<0.05)$ when compared to coated eggs 
Table 1 - Weight loss $(\%)$ and specific gravity $\left(\mathrm{g} \mathrm{cm}^{-3}\right)$ of eggs submitted to different methods of shell treatment according to storage time (days) ${ }^{*}$.

\begin{tabular}{|c|c|c|c|c|c|c|c|c|}
\hline \multirow[t]{2}{*}{ Time (days) } & \multicolumn{2}{|c|}{ Not cleaned and not coated } & \multicolumn{2}{|c|}{---Not cleaned but coated--- } & \multicolumn{2}{|c|}{---Cleaned but not coated--- } & \multicolumn{2}{|c|}{-----Cleaned and coated----. } \\
\hline & Weight loss & Gravity & Weight loss & Gravity & Weight loss & Gravity & Weight loss & Gravity \\
\hline 1 & 0.0 & 1087 & 0.0 & 1085 & 0.0 & 1087 & 0.0 & 1085 \\
\hline 7 & $0.7 \mathrm{~b}$ & $1081 b$ & $0.7 \mathrm{~b}$ & $1081 b$ & $1.09 \mathrm{a}$ & $1084 a$ & $0.8 \mathrm{ab}$ & $1084 a$ \\
\hline 14 & $1.4 \mathrm{ab}$ & 1071 & $1.0 \mathrm{~b}$ & 1075 & $1.7 \mathrm{a}$ & 1070 & $1.4 \mathrm{ab}$ & 1075 \\
\hline 21 & $3.4 \mathrm{a}$ & 1066 & $2.8 \mathrm{~b}$ & 1067 & $3.3 \mathrm{a}$ & 1066 & $2.5 b$ & 1067 \\
\hline 28 & $4.0 \mathrm{~b}$ & $1060 \mathrm{~b}$ & $3.9 b$ & $1061 \mathrm{a}$ & $4.7 \mathrm{a}$ & $1060 \mathrm{~b}$ & $3.9 b$ & $1061 \mathrm{ab}$ \\
\hline 35 & $6.5 \mathrm{ab}$ & 1050 & $5.8 \mathrm{~b}$ & 1051 & $7.6 \mathrm{a}$ & 1050 & $5.9 b$ & 1050 \\
\hline 42 & $8.4 \mathrm{ab}$ & 1040 & $7.7 \mathrm{~b}$ & 1041 & $9.6 \mathrm{a}$ & 1040 & $8.2 \mathrm{~b}$ & 1040 \\
\hline Regression & $\mathrm{L}^{1}$ & $\mathrm{~L}^{2}$ & $\mathrm{~L}^{3}$ & $\mathrm{~L}^{4}$ & $Q^{5}$ & $\mathrm{~L}^{6}$ & $\mathrm{Q}^{7}$ & $\mathrm{Q}^{8}$ \\
\hline \multicolumn{9}{|c|}{ Coefficient of variation: weight loss $12.9 \%$; specific gravity $2.0 \%$} \\
\hline
\end{tabular}

*Significant interaction between the factor and storage time $(\mathrm{P}<0.001)$.

${ }^{* *}$ Means followed by dissimilar letters in the line between the variables are statistically different according to Duncan's test ( $\left.\mathrm{P}<0.05\right)$.

$\mathrm{L}=$ Linear effect; $\mathrm{Q}=$ Quadratic effect; ${ }^{1} \mathrm{y}=-0.849+0.206 \mathrm{x} ; \mathrm{r}^{2}: 0.96 ;{ }^{2} \mathrm{y}=1088.04-1.095 \mathrm{x} ; \mathrm{r}^{2}: 0.99 ;{ }^{3} \mathrm{y}=-0.817+0.187 \mathrm{x} ; \mathrm{r}^{2}: 0.96 ;$ ${ }^{4} \mathrm{y}=1088.25-1.073 \mathrm{x} ; \mathrm{r}^{2}: 0.99 ;{ }^{5} \mathrm{y}=0.0069+0.074 \mathrm{x}+0.0037 \mathrm{x}^{2} ; \mathrm{r}^{2}: 0.99 ;{ }^{6} \mathrm{y}=1088.04-1.095 \mathrm{x} ; \mathrm{r}^{2}: 0.99 ;{ }^{7} \mathrm{y}=0.126+0.0396 \mathrm{x}+0.0036 \mathrm{x}^{2} ; \mathrm{r}^{2}:$ $0.99 ;{ }^{8} \mathrm{y}=1086.68-0.647 \mathrm{x}-0.011 \mathrm{x}^{2} ; \mathrm{r}^{2}: 0.99$.

regardless of being cleaned. Results indicate that sanitization causes physical damage to the egg when it is removed the cuticle that envelops the shell and left the eggs more exposed to gas exchange through shell pores, providing a higher release of carbon dioxide and humidity, resulting in greater egg weight loss during storage time (STRINGHINI et al., 2009). It was possible to observe through electron microscopy that cleaned and disinfected eggshells had suffered changes in their structure, such as cracks and fissures, egg shell thinning and even partial or total cuticle removal (FAVIER et al., 2000). On the other hand, test results indicated that eggs with the covering layer showed lower weight loss, regardless of whether they were cleaned or not $(\mathrm{P}<0.05)$. According to FIUZA et al., (2006), the internal quality of eggs can be preserved longer since the shell is impermeable to carbon dioxide loss. Membranes and covering layers may close shell pores and, for this reason, promote the reduction of humidity and gases transport. (KESTER \& FENNEMA, 1986). ALLEONI \& ANTUNES (2001) observed a decrease in internal egg quality on eggs stored at $25^{\circ} \mathrm{C}$ and $75 \%$ of relative humidity, after seven days of storage.

Regression equations for weight loss versus days of storage (Table 1) indicated a linear relation for not cleaned eggs and a quadratic one for cleaned eggs $(\mathrm{P}<0.05)$. By that, there was weight loss in all methods, regardless of the WPC application. These results corroborate those reported by BARBOSA et al. (2004) who observed egg weight loss with increased storage period $(1,7,14,21,28$ and 35 days). According to POMBO (2003) weight loss in eggs occurs through evaporation and varies depending on the storage time, room temperature, relative humidity and shell porosity. Among these factors, only shell porosity was different in the test, due to different methods used and in this aspect, eggs coated with WPC showed lower weight loss compared to eggs that were not coated.

The particular gravity of the eggs (Table 1) was similar $(\mathrm{P}>0.05)$ in different eggshell treatment methods and throughout storage periods, except on the seventh day, when cleaned eggs showed a higher index than not cleaned eggs even if they were coated or not. Also, it was possible to see the highest index in coated eggs, on the $28^{\text {th }}$ day. According to the results of regression analysis, there was a gradual reduction $(\mathrm{P}<0.05)$ on eggs specific gravity in all treatments throughout the storage period. According to SANTOS et al. (2009) water loss that occurs in the eggs due to evaporation causes a progressive increase in the air chamber and, thus, the specific gravity of the egg decreases.

There was a decrease $(\mathrm{P}<0.05)$ in $\mathrm{HU}$ value of eggs throughout storage, regardless the shell treatment used (Table 2). HU values decrease is associated with a reduction in internal egg quality, and in the case of this test, the variation in the eggs coated with WPC, (85.81 to 56.54 in not cleaned eggs and 78.42 to 50.62 in cleaned eggs) was lower than not coated eggs ( 86.57 to 37.76 in not cleaned 
Table 2 - Haugh units (HU) yolk index (YI\%) of eggs submitted to different methods of shell treatment according to storage time (days) ${ }^{*}$.

\begin{tabular}{|c|c|c|c|c|c|c|c|c|}
\hline \multirow[t]{2}{*}{ Time (days) } & \multicolumn{2}{|c|}{ Not cleaned and not coated } & \multicolumn{2}{|c|}{ Not cleaned but coated } & \multicolumn{2}{|c|}{ Cleaned but not coated } & \multicolumn{2}{|c|}{ Cleaned and coated } \\
\hline & $\mathrm{HU}$ & YI & $\mathrm{HU}$ & YI & $\mathrm{HU}$ & YI & $\mathrm{HU}$ & YI \\
\hline 1 & $86.6 \mathrm{a}$ & 0.44 & $85.8 \mathrm{a}$ & 0.44 & $80.3 b$ & 0.44 & $78.4 b$ & 0.45 \\
\hline 7 & $75.2 \mathrm{ab}$ & $0.43 a b$ & 77.3ab & $0.44 \mathrm{a}$ & $70.8 b$ & $0.42 b$ & $78.2 \mathrm{a}$ & $0.43 \mathrm{ab}$ \\
\hline 14 & $62.9 \mathrm{bc}$ & $0.39 \mathrm{~b}$ & $68.7 \mathrm{a}$ & $0.41 \mathrm{a}$ & $59.4 \mathrm{c}$ & $0.40 \mathrm{ab}$ & $67.0 \mathrm{ab}$ & $0.39 b$ \\
\hline 21 & $53.5 \mathrm{bc}$ & $0.36 \mathrm{a}$ & $61.2 \mathrm{a}$ & $0.37 \mathrm{a}$ & $47.9 \mathrm{c}$ & $0.34 b$ & $57.7 \mathrm{ab}$ & $0.36 \mathrm{a}$ \\
\hline 28 & $51.7 \mathrm{~b}$ & $0.38 \mathrm{a}$ & $62.3 \mathrm{a}$ & $0.36 \mathrm{~b}$ & $39.6 \mathrm{c}$ & $0.36 \mathrm{~b}$ & $56.1 \mathrm{~b}$ & $0.36 \mathrm{~b}$ \\
\hline 35 & $42.1 \mathrm{~b}$ & $0.35 \mathrm{a}$ & $54.2 \mathrm{a}$ & $0.36 \mathrm{a}$ & $30.3 \mathrm{c}$ & $0.33 b$ & $53.5 \mathrm{a}$ & $0.35 \mathrm{a}$ \\
\hline 42 & $37.8 \mathrm{c}$ & $0.32 b$ & $56.5 \mathrm{a}$ & $0.34 \mathrm{a}$ & $29.4 d$ & $0.30 \mathrm{~b}$ & $50.6 \mathrm{~b}$ & $0.31 \mathrm{~b}$ \\
\hline Regression & $\mathrm{Q}^{1}$ & $\mathrm{~L}^{2}$ & $\mathrm{Q}^{3}$ & $\mathrm{~L}^{4}$ & $Q^{5}$ & $\mathrm{~L}^{6}$ & $\mathrm{~L}^{7}$ & $\mathrm{~L}^{8}$ \\
\hline \multicolumn{9}{|c|}{ Coefficient of variation: HU $6.01 \%$; specific gravity $3.45 \%$} \\
\hline
\end{tabular}

\footnotetext{
${ }^{* *}$ Significant interaction between the factor and storage time $(\mathrm{P}<0.001)$.

${ }^{* * *}$ Means followed by dissimilar letters in the line between the variables are statistically different according to Duncan's test $(\mathrm{P}<0.05)$. $\mathrm{L}=$ Linear; $\mathrm{Q}=$ Quadratic; ${ }^{1} \mathrm{y}=87.690-1.912 \mathrm{x}+0.018 \mathrm{x}^{2} ; \mathrm{r}^{2}: 0.99 ;{ }^{2} \mathrm{y}=0.439-0.003 \mathrm{x} ; \mathrm{r}^{2}: 0.90 ;{ }^{3} \mathrm{y}=87.210-1.573 \mathrm{x}-0.020 \mathrm{x}^{2} ; \mathrm{r}^{2}: 0.97 ;{ }^{4} \mathrm{y}=$ $0.445-0.002 \mathrm{x} ; \mathrm{r}^{2}: 0.92 ;{ }^{5} \mathrm{y}=83.462-2.051 \mathrm{x}+0.017 \mathrm{x}^{2} ; \mathrm{r}^{2}: 0.99 ;{ }^{6} \mathrm{y}=0.440-0.003 \mathrm{x} ; \mathrm{r}^{2}: 0.93 ;{ }^{7} \mathrm{y}=78.811-0.745 \mathrm{x} ; \mathrm{r}^{2}: 0.92 ;{ }^{8} \mathrm{y}=0.445-$ $0.003 x ; r^{2}: 0.94$.
}

eggs and 80.33 to 29.44 in cleaned ones), between the beginning and the end of the storage period. Cleaning processes and WPC coverage influenced $\mathrm{HU}$ values from the first day of storage being lower $(\mathrm{P}<0.05)$ in cleaned eggs. After 14 days of storage, $\mathrm{HU}$ values remained higher in the not cleaned eggs $(\mathrm{P}<0.05)$. However, they received WPC covering layer compared to the not cleaned and not coated eggs, in which it was possible to observe the lowest HU values until the last period assessed.

Despite knowing that the cleaning process causes physical damage to the egg and consequently, a decrease in the internal egg quality, the process often becomes indispensable because it improves the appearance of eggs and influences the consumer acceptance (CASTELLÓ LLOBET et al., 1989). Also, it improves shell's bacteriological quality, reducing the risk of contamination and threat to food security (STRINGHINI et al., 2009). In this context, WPC coating is a viable alternative because it behaves as an artificial cuticle, reducing gases exchange through shell's pores while maintaining internal egg quality longer, including the eggs that need to go through the cleaning process. ALLEONI \& ANTUNES (2001) compared HU values of eggs stored at a cold temperature $\left(8^{\circ} \mathrm{C}\right)$ and found $\mathrm{HU}$ values of 60 after 21 days of storage, whereas the HU value was 70 for eggs coated with WPC.

Brazilian legislation does not use HU values as a parameter for assessing internal egg quality. However, the eggs' HU values from this essay, with 42 days of storage, can be compared to the Quality
Control Program approved by the U.S. According to the Department of Agriculture (USDA, 2000), the eggs that were not coated with WPC, cleaned or not, or those that were not cleaned, but received WPC coating, would be classified as average quality eggs (HU of 59 to 30). Cleaned, but not coated eggs would be classified as low-quality eggs (HU of 29 to 0 ).

With prolonged egg storage, various attributes of yolk's quality are lost. During storage, the yolk absorbs water from the albumen, becoming decentralized and less dense (ORDÓNEZ, 2005). Thus, yolk's consistency is another criterion for determining egg's internal quality, which is measured by using the egg yolk index (Table 2). As a result, it was possible to find that cleaned eggs covered with WPC had significantly higher yolk index $(\mathrm{P}<0.05)$ from the seventh day until the end of the storage period. There was a comparison with cleaned eggs that did not receive WPC coating, except for the $14^{\text {th }}$ and $28^{\text {th }}$ days, when there was a similarity between methods $(\mathrm{P}>0.05)$. It appeared a significant linear decrease $(\mathrm{P}<0.05)$ in the yolk index during storage for all shell treatment methods (Table 2). Nevertheless, all yolk indexes were in accordance with the pattern determined for fresh eggs, which should range from 0.30 to 0.50 (ROMANOFF \& ROMANOFF, 1963; MORAIS et al., 1997).

Storage time and shell treatment methods influenced $(\mathrm{P}<0.05) \mathrm{pH}$ values of the albumen in all periods assessed (Table 3). Eggs that did not receive WPC coating, regardless of being cleaned or not, showed higher $\mathrm{pH}$ values $(\mathrm{P}<0.05)$ throughout the 
Table 3 - pH of egg albumen submitted to different methods of shell treatment according to storage time (days) ${ }^{*}$.

\begin{tabular}{|c|c|c|c|c|}
\hline \multirow{2}{*}{ Storage time (days) } & \multicolumn{4}{|c|}{ - } \\
\hline & Not cleaned and not coated & Not cleaned but coated & Cleaned but not coated & Cleaned and coated \\
\hline 1 & $8.78 \mathrm{ab}$ & $8.62 b$ & $8.93 \mathrm{a}$ & $8.78 \mathrm{ab}$ \\
\hline 7 & $9.15 \mathrm{a}$ & $8.86 \mathrm{~b}$ & $9.24 \mathrm{a}$ & $8.88 b$ \\
\hline 14 & $9.69 \mathrm{a}$ & $9.56 \mathrm{~b}$ & $9.70 \mathrm{a}$ & $9.54 \mathrm{~b}$ \\
\hline 21 & $9.54 \mathrm{a}$ & $9.49 b$ & $9.54 \mathrm{a}$ & $9.43 \mathrm{c}$ \\
\hline 28 & $9.41 \mathrm{a}$ & $9.36 \mathrm{~b}$ & $9.42 \mathrm{a}$ & $9.31 \mathrm{c}$ \\
\hline 35 & $9.28 \mathrm{a}$ & $9.23 b$ & $9.30 \mathrm{a}$ & $9.20 \mathrm{~b}$ \\
\hline 42 & $9.17 \mathrm{a}$ & $9.03 \mathrm{~b}$ & $9.19 \mathrm{a}$ & $9.03 \mathrm{~b}$ \\
\hline Regression & $\mathrm{Q}^{1}$ & $\mathrm{Q}^{2}$ & $\mathrm{Q}^{3}$ & $\mathrm{Q}^{4}$ \\
\hline \multicolumn{5}{|c|}{ Coefficient of variation $=0.55 \%$} \\
\hline
\end{tabular}

* Significant interaction between the factor and storage time $(\mathrm{P}<0.001)$.

** Means followed by dissimilar letters in the line between the variables are statistically different according to Duncan's test $(\mathrm{P}<0.05)$.

$\mathrm{Q}=$ Quadratic; ${ }^{1} \mathrm{y}=8.768+0.072 \mathrm{x}-0.002 \mathrm{x}^{2} ; \mathrm{r}^{2}: 0.78 ;{ }^{2} \mathrm{y}=8.514+0.084 \mathrm{x}-0.002 \mathrm{x}^{2} ; \mathrm{r}^{2}: 0.84 ;{ }^{3} \mathrm{y}=8.918+0.061 \mathrm{x}-0.001 \mathrm{x}^{2} ; \mathrm{r}^{2}: 0.76 ;{ }^{4} \mathrm{y}=$ $8.666+0.067 \mathrm{x}-0.001 \mathrm{x}^{2} ; \mathrm{r}^{2}: 0.78$.

storage period. There was an exception in the $1^{\text {st }}$ day, when not cleaned eggs showed similar results $(\mathrm{P}>0.05)$ to the others. It is worth mentioning that albumen's $\mathrm{pH}$ had a progressive increase in all methods applied, reaching the maximum value after 14 days of storage. After that, there was a reduction of $\mathrm{pH}$ values resulting in a quadratic behavior of the regression equations. GIAMPIETRO-GANECO et al. also obtained these results (2012), in which the albumen $\mathrm{pH}$ values tend to increase with storage, suffering further reduction, whereas values are close to the fresh egg's values, after 56 days. It is related to the changes that occur in the egg, during storage, and associated with the exchange of carbon dioxide through the shell. These reactions involve carbonic acid, one of the albumen's buffer system components, which dissociates to form water and carbon dioxide. Then, it diffuses through the shell and disappears into the environment, under natural conditions. Due to this release, the albumen $\mathrm{pH}$ increases cause the chemical dissociation of protein complex (ROMANOFF \& ROMANOFF, 1963; ORDÓNEZ, 2005). By that, during storage, the coated eggs with WPC maintained lower $\mathrm{pH}$ values than the not coated ones, and coating may promote the eggshell pores closing. Thus, it reduces gas changes through the shell and the release of carbon dioxide.

\section{CONCLUSION}

The whey protein concentrate coating applied to eggs cleaned or not improves internal egg quality. Thus, it becomes a feasible alternative to preserve commercial eggs, cleaned or not, stored at room temperature and minimizing the loss of internal egg quality with storage time.

\section{ACKNOWLEDGEMENTS}

The authors are grateful to Programa de Bolsas de Monitoria de Pós-Graduação (PROMOP) of UDESC.

\section{REFERENCES}

ALLEONI, A.C.C.; ANTUNES, A.J. Haugh unit as a measure of the quality of hen eggs stored under refrigeration. Scientia Agrícola, Piracicaba, v.58, p.681- 685, 2001. Available from: $<$ http://dx.doi. org/10.1590/S0103-90162001000400005>. Accessed: May 18, 2012. doi: 10.1590/S0103-90162001000400005.

ANTUNES, A.J. Funcionalidade de proteínas do soro de leite bovino. Barueri: Manole, 2003. 135p.

BARBOSA, N.A.A. et al. Effect of time and storage conditions on the internal quality of eggs hens. Brazilian Journal Poultry Science, supl.6, p.60-65, 2004.

BARBOSA, N.A.A. et al. Quality of eggs from commercial layers stored for different times and environment conditions. ARS Veterinária, v.24, n.2, p.127-133, 2008. Available from: <http:// arsveterinaria.org.br/index.php/ars/article/view/182/150>. Accessed: Feb. 22, 2012. doi: 10.15361/2175-0106.2008v24n2p127-133.

BRASIL, Ministério da Agricultura Pecuária e Abastecimento. Secretaria de Inspeção de Produto de Origem Animal. Portaria n. 01 de 21 de fevereiro de 1990. Normas Gerais de Inspeção de Ovos e Derivados. Diário Oficial [da] República Federativa do Brasil. Brasília, 1990. Available from: <http://sistemasweb. agricultura.gov.br/sislegis $>$. Accessed: Feb. 10, 2013.

CASTElló LlOBET, J.A. et al. Producción de huevos. Barcelona: Real Escuela de Avicultura, 1989. 367p.

FAVIER, G.I. et al. Reduction of Yersinia enterocolitica and mesophilic aerobic bacteria in egg-shell by washing with surfactants 
and their effect on the shell microstructure. Food Microbiology, v.17, p.73-81, 2000. Available from: <http://onlinelibrary.wiley. com/doi/10.1111/j.1365-2672.2008.04022.x/pdf>. Accessed on: Jan. 19, 2011. doi: 10.1111/j.1365-2672.2008.04022.x.

FIUZA, M.A. et al. Effect on time between oviposition and the beginning of cool storage on hatchability of broiler breeder eggs. Arquivos Brasileiros de Medicina Veterinária e Zootecnia, v.58, p.408-413, 2006. Available from: <http://www.scielo.br/scielo. php?script $=$ sci_arttext\&pid=S0102-09352006000300019\&lng $=$ en\&nrm $=$ iso $>$. Accessed: July. 12, 2013. doi: 10.1590/S010209352006000300019 .

GIAMPIETRO-GANECO, A. et al. Comparative study of egg quality characteristics stored in domestic refrigerators. Ars Veterinária, Jaboticabal, v.28, n.2, 100-104, 2012. Available from: <http:// arsveterinaria.org.br/index.php/ars/article/view/429>. Accessed: Jun. 11, 2013. doi: 10.15361/2175-0106.2012v28n2p100-104 .

GENNADIOS, A. et al. Edible coatings and films based on proteins. In: KROCHTA, J.M. et al. (Ed.). Edible coatings and films to improve food quality. Lancaster: Technomic Publ, 1994. p.201-277.

KESTER, J.J. FENNEMA, O.R. Edible films and coatings: a review. Food Technology, v.40, n.12, p.47-59, 1986. Available from: <http://agris.fao.org/agris-search/search. do?recordID=US8836195>. Accessed: Jun. 14, 2011.

MORAIS, C.F.A. et al. Internal quality of commercial eggs in Uberlândia retail stores. Arquivo Brasileiro de Medicina Veterinária e Zootecnia, v.49, p.365-373, 1997.
NESHEIM, M.C. et al. Poultry production. 12.ed. Philadelphia: Lea \& Febiger, 1979. 339p.

ORDÓNEZ, J. A. Ovos e produtos derivados. In: ORDÓNEZ, J. A. (Ed.). Tecnologia de alimentos: alimentos de origem animal. Porto Alegre: Artmed, 2005. p. 269-279.

POMBO, C.R. Effect of thermical treatment on weight and internal quality of shell eggs. Rio de Janeiro, 2003. 74f. Dissertação (Mestrado em Veterinária) - Faculdade de Veterinária, Universidade Federal Fluminense, RJ.

ROMANOFF, A.L.; ROMANOFF, A.J. The avian egg. 2.ed. New York: John Wiley \& Sons, 1963. 918p.

SANTOS, M.S.V. et al. Effect of temperature and storage of eggs. Ciência e Tecnologia de Alimentos, v.29, n.3, p.513-517, 2009. Available from: http://www.scielo.br/scielo.php? script $=$ sci arttext\&pid $=\mathrm{S} 0101-20612009000300009 \& \operatorname{lng}=\mathrm{en} \& \mathrm{nrm}=\mathrm{iso}$. Accessed: Jul. 8, 2013. doi: 10.1590/S0101-20612009000300009.

SAS Institute. SAS user's guide: statistics. Cary, 1999. Release 8.02.

STRINGHINI, M.L.F. et al. Bacteriological characteristics of washed and unwashed laying hen's eggs. Ciência Animal Brasileira, v.10, n.4, p.1317-1327, 2009. Available from: <http:// www.revistas.ufg.br/index.php/vet/article/download/4209/5955>. Accessed: Oct. 13, 2012.

USDA (UNITED STATES DEPARTMENT OF AGRICULTURE). Egg-grading manual. Washington, 2000. N,75. Available from: <http://www.ams.usda.gov/AMSv1.0/ getfile?dDocName=STELDEV3004502 $>$. Accessed: May 13, 2013. 